mag. Marko

Radovan, Andragoški center Slovenije

\section{ALI SO BREZPOSELNI MOTIVIRANI ZA IZOBRAŽEVANJE?}

\title{
POVZETEK
}

$V$ članku se avtor sprašuje o dejavnikih, ki vplivajo na motiviranost brezposelnih za izobraževanje in učenje. Osrednji namen raziskave je bil ugotoviti, ali je motivacija brezposelnih predvsem odraz individualnih manifestacij socialnih pritiskov, ki posameznika "silijo" $v$ izobraževanje oz. ga od njega odvračajo, ali pa je motivacija odvisna predvsem od lastnih motivov, potreb in pričakovanj brezposelnih.

Rezultati so pokazali, da so za motivacijo za izobraževanje pri obravnavani skupini brezposelnih najpomembnejše spodbude s strani referenčnih skupin in samoučinkovitost. Socialne norme so dejavnik, ki vpliva na izobraževalne namere anketirancev, in so povezane z ekonomskimi možnostmi, ki jih nudijo njihove pomembne referenčne skupine, zadevajo pa tudi spodbujanje $k$ doseganju višjih stopenj izobrazbe. Samoučinkovitost ima vpliv predvsem na zastavljanje dolgoročnih izobraževalnih ciljev (aspiracij), povezana pa je tudi z učnim odnosom brezposelnih do učenja (notranja oz. zunanja motivacija).

Ključne besede: motivacija, brezposelnost, izobraževanje, norme, referenčne skupine, samoučinkovitost

\section{UVOD}

Leta 2000 je Andragoški center Slovenije opravil evalvacijo srednješolskega formalnega poklicnega in strokovnega izobraževanja brezpoșelnih (Program 5000), ki ga je leta 1997 kot enega od ključnih programov aktivne politike zaposlovanja sprejela Vlada Republike Slovenije. Eno od zastavljenih evalvacijskih vprašanj se je dotikalo tudi motivacije brezposelnih za izobraževanje. Da bi podrobneje spoznali motivacijsko strukturo brezposelnih za izobraževanje, smo izvedli raziskavo "Motivacija brezposelnih za izobraževanje: vrednotni, kognitivni in socialno-kulturni vidiki motivacije odraslih za izobraževanje". Z zbranimi rezultati smo skušali povečati naše razumevanje motivov, vrednot in pričakovanj brezposelnih in njihovega vpliva na motivacijo za izobraževanje.

$\mathrm{V}$ članku bodó predstavljene temeljne ugotovitve te raziskave.

\section{PROBLEM IN CILII RAZISKAVE}

\section{Opredelitev problema raziskave}

V izobraževanju odraslih se velikokrat sprašujemo o razlogih in dejavnikih, ki pripomorejo $\mathrm{k}$ odločitvi posameznika, da se bo udeležil izobraževanja. V zgodnjem obdobju raziskovanja motivacije odraslih za izobraževanje je bilo pod vplivom Maslowa na področju izobraževanja odraslih opravljenih veliko raziskav, v katerih so ugotavljali predvsem naravo motivov in izobraževalnih 
Analize kažejo, da je izobraževanje odraslih tesno povezano s potrebami $v$ poklicu in zaradi tega udeležba $\vee$ izobraževanju močno zaznamovana $\mathrm{z}$ možnostmi, ki jih posamezniku nudi delovni položaj.

potreb, ki odrasle vodijo $\mathrm{v}$ izobraževanje. Trdili bi lahko, da so bile izobraževalne potrebe določen čas poglaviten konstrukt, na podlagi katerega se je ugotavljala motivacija za učenje in izobraževanje. Sodobne motivacijske teorije sicer tudi poudarjajo raznolikost potreb in motivov, vendar se $\mathrm{v}$ obravnavi posameznikove motivacije osredotočajo predvsem na preučevanje kognitivnih procesov, ki vedenje in aktivnosti usmerjajo, jim dajejo moč in vztrajnost (Becker \& Gibson, 1999; Howard, 1989; Pryor, 1990; Rubenson, 1987, itn.).

Prejšnje raziskave so pokazale, da so motivi odraslih za izobraževanje bolj pragmatične narave, saj je končni cilj izobraževanja večinoma povezan $\mathrm{z}$ izboljšanjem poklicnega in s tem ekonomskega položaja posameznika.

$\mathrm{V}$ tem kontekstu so razumljive tudi ugotovitve Courtneya (1992), ki je opravil metaanalizo raziskav o udeležbi odraslih $\mathrm{v}$ izobraževanju. Analiza je pokazala, da deluje izobraževanje odraslih kot kontinuiteta formalnega šolanja, saj se zanj odločajo predvsem tisti, ki so bili uspešni že pri rednem šolanju. Udeležba $v$ formalnem izobraževanju odraslih je zato bolj posledica kot pa sredstvo ekonomske moči; udeležujejo se ga predvsem posamezniki, ki so že uspešni, manj pa tisti, ki si taki šele želijo postati.

Med tistimi, ki so uspeha nedvomno potrebni, so tudi brezposelni. Izobraževanju brezposelnih namenja stroka še posebno pozornost, saj cela vrsta raziskav (npr. Furnham, 1994) opozarja na nekatere psihosocialne značilnosti, ki se razvijejo v obdobju brezposelnosti in motivacijo zavirajo. Izha- jajoč iz povedanega smo problematiko raziskave osredotočili predvsem na vprašanja, koliko je moč domnevati, da so izobraževalne namere (motivacija) vzorca brezposelnih predvsem individualne manifestacije socialnih pritiskov (socialnih norm in drugih zunanjih pogojev), ki posameznika "potiskajo" v izobraževanje ali pa ga od njega odvračajo. Ali pa je pravilnejše domnevati, da je motivacija brezposelnih za
Za izobraževanje se odločajo predvsem tisti, ki so bili uspešni že pri rednem šolanju. izobraževanje odvisna predvsem od njihovih lastnih motivov, potreb in pričakovanj? Iz tega zornega kota bi bila lahko njihova stališča do izobraževanja tisti ključni dejavnik, ki zmanjšuje (ali povečuje) njihovo motiviranost.

Glede na dosedanje poznavanje problematike izobraževanja brezposelnih bi lahko na obe vprašanji odgovorili pritrdilno. Najprej moramo izpostaviti, da so brezposelni $\mathrm{z}$ izgubo zaposlitve ali neuspešnim iskanjem prve zaposlitve $v$ izredno neugodnem ekonomskem položaju, ki v marsičem vpliva na njihovo življenje in tudi na njihove možnosti za vključitev v izobraževanje. Po drugi strani moramo opozoriti na (že omenjene) psihološke posledice brezposelnosti, ki se kažejo predvsem v negativnem razvoju samopodobe, osebnostnih sprememb in sprememb vrednot, negativnega odnosa do dela,
Psiholoska posledica brezposelnosti se kaže predvsem $v$ negativni samopodobi. občutka neobvladljivosti življenja in navsezadnje tudi negativnih stališč do izobraževanja.

\section{IZBOR VZORCA IN POSTOPEK ${ }^{1}$}

Za pridobivanje podatkov o motivaciji udeležencev za izobraževanje smo predvideli vzorec 300 udeležencev, ki smo ga pridobili 


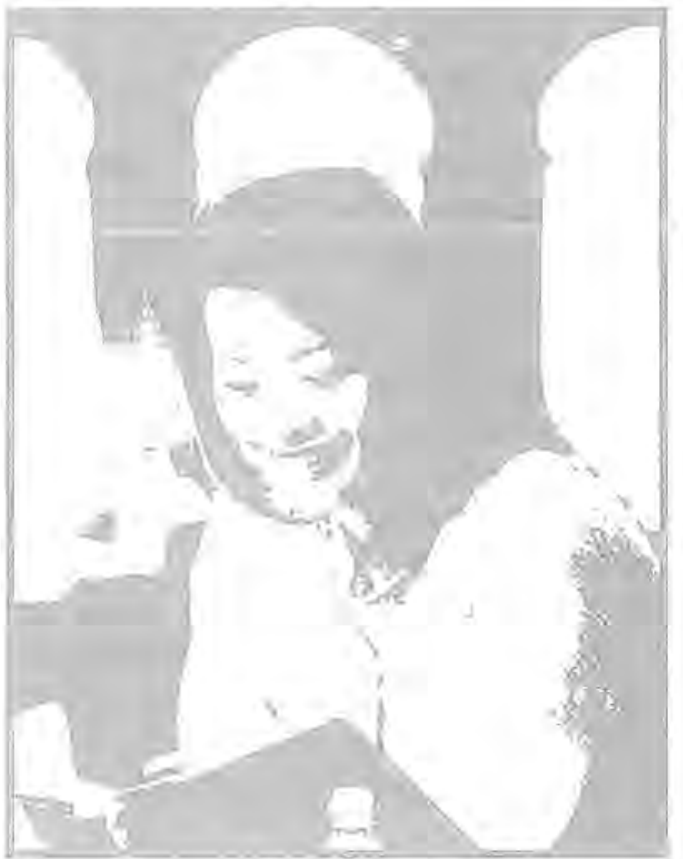

iz izhodiščne baze vzorca brezposelnih, vključenih v evalvacijo Programa 5000 v izvedbi Andragoškega centra Slovenije (Drofenik, 2001). Vzorec je bil izbran na začetku šolskega leta 2000/01 med tistimi, ki nadaljujejo šolanje iz preteklega šolskega leta.

Anketo je izpolnilo 337 udeležencev, naknadno smo izločili 11 anket, zato je bilo končno število preizkušancev, vključenih v analizo, nekoliko manjše, 326.

Za preizkušance smo oblikovali vprašalnik, ki smo ga poimenovali "Vprašalnik motivacije za izobraževanje in učenje". Sestavljen je iz lestvic različnih avtorjev, ki smo jih priredili potrebam odraslih udeležencev izobraževanja: (a) lestvica stališč, (b) subjektivne norme, (c) lestvica vrednot (Musek, 2000), (č) lestvica notranje in zunanje motivacije pri učenju ter (d) lestvica samoučinkovitosti pri učenju (Bandura, 1986).

Priprava vprašalnika in izvedbe ter izvedba raziskave so potekale jeseni leta 2000 . Zbiranje podatkov je bilo skupinsko, za reševanje pa so brezposelni porabili približno 20 minut.

\section{Sociodemografske in druge značilnosti vzorca}

Med anketiranimi je bilo največ žensk ( $73 \%$ ) in mlajših od 25 let (42\%). Po starostni strukturi je bilo $v$ raziskovanje najmanj zajetih brezposelnih, starih od 36 do 49 let $(16 \%)$. To starostno razmerje niti ni presenetljivo, če upoštevamo dejstvo, da so se prednostno v Program 5000 vključevali mlajši brezposelni. V vzorcu so prevladovali udeleženci $\mathrm{s}$ končano triletno poklicno srednjo šolo (46\%); sledili so tisti s končano osnovno šolo $(32 \%)$ in končano eno- ali dveletno poklicno srednjo šolo $(21 \%)$. V vzorcu je bilo največ takih, ki so bili vključeni v program Podjetniško poslovanje poslovni sekretar $(26 \%)$, sledili so programi Gostinska dela (16 \%), Ekonomskokomercialni tehnik (14\%) in Vrtnar-cvetličar $(10,4 \%)$. Delež vključenih v ostale programe je bil manjši od $10 \%$.

Ker prištevamo brezposelne med "šibkejše" učence, smo jih povprašali tudi po razlogih, zaradi katerih so prejšnje (redno) izobraževanje prekinili. Med navedbami prevladujejo finančni razlogi $(22 \%), 16 \%$ jih je navedlo, da jim v šoli ni šlo dobro, $13 \%$ pa, da niso marali šole. Ostali deleži ovir so manjši: $5 \%$ jih je navedlo osebne probleme, $3 \%$ pa družinske obveznosti in zdravstvene razloge. Za to vprašanje je značilno, da je veliko odgovorov manjkajočih - relativno velik delež anketiranih je odgovoril z "drugo" (11\%), prav tako velik delež pa jih za svojo prekinitev ni želel navesti razloga in so odgovorili z "ne vem" (14\%) ali pa nanj sploh niso odgovorili $(13 \%)$. Ti rezultati kažejo na občutljivost teme, ki jo s kvantitativnim raziskovanjem niti ni mogoče zajeti $\mathrm{v}$ celoti. Vsekakor bi bilo vredno te podatke obogatiti še s kvalitativnimi metodami raziskovanja. 


\section{UGOTOVITVE}

Posameznikovo motiviranost za nadaljevanje izobraževanja smo merili s pomočjo dveh spremenljivk:

1. Izobraževalne namere - Anketiranci so dajali svoje ocene v ocenjevalnem razponu od -3 ("po koncu izobraževanja v Programu 5000 se bom zaposlil ...") do +3 ("po koncu izobraževanja v Programu 5000 bom nadaljeval izobraževanje ..."). Rezultati kažejo, da se namerava približno enak delež preizkuŠancev po zaključku izobraževanja zaposliti ( $24 \%$ ); podoben delež pa jih namerava svoje izobraževanje nadaljevati (23\%). Petina anketirancev je bila glede svoje poti še neopredeljenih (19\%).

2. Aspiracije - Tretjina anketirancev želi le izobrazbo, za katero se trenutno šolajo (34 $\%)$; to so tisti brezposelni, ki se v prihodnosti ne nameravajo več izobraževati, vsaj ne formalno. Slaba polovica vprašanih (48\%) si želi $v$ prihodnosti doseči eno izobrazbeno stopnjo več od te, ki jo bo dosegla $v$ Programu 5000; $10 \%$ vprašanih si želi dve izobrazbeni stopnji više; $8 \%$ pa tri ali štiri (le ena brezposelna oseba si želi doseči štiri izobrazbene stopnje več).

Glavni cilj pričujoče naloge je bil raziskati motivacijske značilnosti brezposelnih, ki so se izobraževali v okviru Programa 5000. Omenili smo že, da je bil poglaviten del našega raziskovalnega interesa usmerjen predvsem na identifikacijo psiholoških dejavnikov, ki vplivajo na izobraževalne namere in aspiracije brezposelnih.

Predvideli smo, da za brezposelne $\mathrm{v}$ Programu 5000 velja motivacijski model, v katerem so stališča, subjektivna norma, samoučinkovitost in vrednote tisti dejavniki, ki vplivajo na njihovo motivacijo za nadaljevanje izobraževanja. Na podlagi rezultatov sklepamo, da ne moremo povsem potrditi omenjene hipoteze. Izsledki analize kažejo na to, da sta $v$ primeru brezposelnih, ki so vključeni v Program 5000, najpomembnejša dejavnika subjektivna norma in samoučinkovitost (mnenje o kompetentnosti pri učenju), Prva spremenljivka vpliva predvsem na izobraževalne namere, druga pa na aspiracije anketirancev. Stališča in vrednote se niso pokazale kot pomemben dejavnik $\mathrm{v}$ nobenem motivacijskem modelu. Povezanost med stališči in namenom za nadaljevanje izobraževanja je sicer statistično pomembna, vendar pa izredno nizka. To je do neke mere presenetljivo, saj se je $\mathrm{v}$ preteklosti že uveljavilo prepričanje, da marginalizirane skupine (med katere uvrščamo tudi brezposelne) pri vključevanju $\mathrm{v}$ izobraževanje močno ovirajo negativna stališča do izobraževanja. Iz naše raziskave pa sledi, da za izbrani vzorec brezposelnih te ugotovitve ne veljajo. Dodatne statistične analize so sicer pokazale, da kljub temu obstajajo določene razlike $\mathrm{v}$ posameznih prepričanjih, ki tvorijo latentno dimenzijo stališč glede motivacije za izobraževanje.

Eden od razlogov za statistično nepomembnost stališč je zagotovo značilnost vzorca. V raziskavo je bila namreč vključena prva generacija brezposelnih $v$ Programu 5000 , za katere se je izkazalo, da so motivirani za izobraževanje in se zavedajo

Ugotovili smo, da se bolj in manj motivirani brezposelni med seboj ne razlikujejo toliko $\mathrm{v}$ vrednotenju ponujenih ciljev, ampak do največjih razlik prihaja predvsem pri ocenjevanju vedenjskih prepričanj glede izobraževanja. To pomeni, da je večina anketirancev podobno vrednotila ponujene cilje, niso pa bili tako enotni, ali jih lahko z izobraževanjem dosežejo ali ne. Ti rezultati se nekako ujemajo $\mathrm{z}$ raziskavami, s katerimi so ugotovili, da manj kvalificirani delavci izobraževanja ne vidijo kot sredstva socialne mobilnosti (Fuller \& Saunders, 1991). 
njegove vrednosti. Veliko jih je kar samih stopilo do svetovalca na zavodu za zaposlovanje in uredilo potrebne formalnosti za vpis v Program 5000. Očitno gre za skupino mlajših brezposelnih, za katere bi lahko rekli, da niso brezposelni $\mathrm{v}$ pravem pomenu besede. Iz rednega izobraževanja so izpadli dokaj zgodaj in prave brezposelnosti niso niti izkusili, saj so se kmalu vključili $v$ izobraževanje odraslih. Študija je pokazala, da se brezposelni zavedajo pomembnosti izobrazbe za pridobitev poklica; kar nekaj je bilo tudi takih, ki so bili v izobraževanje že vključeni in so si ga plačevali sami, ko pa se je ponudila priložnost, so svoje izobraževanje prenesli pod okrilje Programa 5000. Vse to kaže, da opazovani vzorec ni tipična skupina brezposelnih in predvidevamo, da je to eden od razlogov za relativno pozitivna stališča respondentov do izobraževanja. Prepričani smo, da bi vključitev $\mathrm{v}$ vzorec tudi tistih brezposelnih, ki se niso želeli izobraževati, pokazala veliko večji pomen stališč.

Omenjeno je že bilo, da so se spodbude referenčnih skupin (subjektivne norme) izkazale za najpomembnejši dejavnik mo-

Najmočnejši motivacijski element so spodbude referenčnih skupin. tivacije brezposelnih za izobraževanje. Nadaljnja analiza bi pokazala, koliko so te spodbude po eni strani povezane $\mathrm{z}$ ekonomskimi možnostmi, ki jih nudijo njihove pomembne socialne skupine

(družina, partner, prijatelji), koliko pa je njihova podpora povezana $s$ pozitivnim vrednotenjem doseganja višjih stopenj izobrazbe. Predvidevamo lahko, da je subjektivna norma tudi zaradi tega statistično pomembno povezana $\mathrm{z}$ izobraževalnimi namerami in aspiracijami.

$\mathrm{V}$ zvezi $\mathrm{z}$ aspiracijami je treba opozoriti na ugotovitev, da je značilnost brezposelnih tudi precej kratkoročna motivacija za doseganje višjih izobrazbenih stopenj. To ugotovitev
Iz rezultatov raziskave je razvidno, da so svetovalci na zavodu tisti, ki brezposelne najbolj spodbujajo $\mathrm{k}$ čim hitrejši zaposlitvi. To je zaradi siceršnjega položaja brezposelnih sicer razumljivo, vendar bi bilo $v$ zvezi s tem priporočljivo, da bi svetovalni delavci spodbujali brezposelne, ko je to možno, tudi $\mathrm{k}$ vključevanju $\mathrm{v}$ nadaljnje izobraževanje, jim nudili ustrezne informacije o možnostih financiranja itd.; kjer ekonomske razmere tega ne dovoljujejo, pa bi morali brezposelne vključevati $\mathrm{v}$ motivacijske programe in spodbujati izobraževanje tudi po pridobljeni zaposlitvi. Hkrati ne smemo pozabiti tudi na ekonomski vidik pripravljenosti za izobraževanje. Možnost kritja materialnih stroškov izobraževanja je pomemben dejavnik, ki omogoča in motivira brezposelne za izobraževanje.

prav tako podpirajo odgovori $\mathrm{v}$ zvezi $\mathrm{z}$ ovirami, ki so brezposelnim onemogočale izobraževanje pred vključitvijo v Program 5000 (Drofenik, 2001). Enako kažejo tudi ugotovitve naše analize - podatki namreč kažejo, da so aspiracije tudi tistih brezposelnih, ki so načeloma bolj motivirani za nadaljevanje izobraževanja, relativno nizke. Iz tega lahko sklepamo, da motiviranost za izobraževanje sicer obstaja, vendar je $\mathrm{v}$ funkciji najhitrejše možne poti do zaposlitve in izboljšanja ekonomskega položaja. Bolj kot njihov neposredni interes za čimprejšnjo zaposlitev je zaskrbljujoča njihova dolgoročna nemotiviranost za doseganje izobrazbe.

Vključitev posameznika v izobraževalni program je šele prvi korak na poti do pridobljene izobrazbe. Marsikateri posameznik zelo hitro obupa nad obiskovanjem pouka (ki je v Programu 5000 obvezno) in še pred zaključkom opusti šolanje. Pomemben psihološki dejavnik, ki vpliva na vztrajnost, trud in motivacijo pri učenju, je samoučinkovitost 
(Bandura, 1986), ki opisuje posameznikova prepričanja o kompetentnosti za učenje. Naša raziskava je pokazala, da anketiranci na lestvici samoučinkovitosti (12 navedb) najvišje ocenjujejo prepričanja, da lahko uspešno zaključijo šolanje, da so zmožni reševati težke naloge in so pri tem vztrajni. Največ težav jim dela zmožnost koncentracije, pomnjenje učne snovi in učenje zahtevne snovi.

Kar zadeva vpliv mnenja o samoučinkovitosti pri učenju, smo ugotovili, da je povezanost med samoučinkovitostjo in izobraževalno namero nizka, $\mathrm{z}$ aspiracijami pa zmerna. Statistična analiza je pokazala, da samoučinkovitost ni dejavnik, s katerim bi lahko predvidevali namere brezposelnih za vključitev $v$ izobraževanje neposredno po končanem izobraževanju v Programu 5000. Kot sem že poudaril, je tak rezultat nekoliko presenetljiv, saj druge podobne raziskave večinoma potrjujejo vpliv samoučinkovitosti tako na intenco (motivacijo) kot tudi na vedenje samo. Za razumevanje rezultatov na lestvici samoučinkovitosti veljajo podobna opozorila kot pri stališčih. V raziskavah, kjer je bil analiziran vpliv samoučinkovitosti na vedenje, le-to ni bilo pod močnim socialnim pritiskom. V takih primerih je povsem razumljivo, da je vloga samoučinkovitosti in stališč pomembnejša od subjektivne norme. $\mathrm{Za}$ brezposelne je odločitev za izobraževanje pod močnim vplivom ekonomskih in socialnih imperativov in zato se samoučinkovitost $v$ tem kontekstu ne izkazuje kot dejavnik, ki bi potisnil jeziček pri neposredni nameri brezposelnega, da nadaljuje izobraževanje na višji stopnji. Rezultati pa potrjujejo naša predvidevanja na področju aspiracij. Med izbranimi prediktorskimi spremenljivkami je samoučinkovitost edini psihološki dejavnik, na podlagi katerega bi lahko napovedovali aspiracije. Mnenje o sposobnostih za učenje je torej pomembnejše pri oblikovanju aspiracij kot socialna podpora (materialna ali moralna) za doseganje višjih izobrazbenih stopenj.

Presenetljivo je tudi, da so brezposelni na splošno izkazovali visoko raven zaupanja v svoje učne sposobnosti. Sam menim, da je najpomembnejši razlog za tako visoko izraženo raven samoučinkovitosti treba iskati $\checkmark$ naravi njenega funkcioniranja. Za samoučinkovitost je namreč značilno, da je najboljši napovedovalec vedenja $v$ situacijah, $k i$ jih posameznik zaznava kot srednje zahtevne (Bezinović, 1988). Prav tako je za samoučinkovitost značilno, da je izredno pomemben dejavnik takrat, ko se za določeno dejavnost šele odločamo in Na podlagi samoučinkovitosti lahko napovedujemo aspiracije za izobraževanje.

lahko o naši ustreznosti in uspešnosti pri njej sklepamo le na podlagi prejšnjih izkušenj. Če imamo $v$ mislih ti dve značilnosti samoučinkovitosti, si lahko pojasnimo, zakaj se samoučinkovitost ni izkazala kot pomembnejši dejavnik $v$ izobraževalnih namerah. Anketiranje brezposelnih je potekalo $v$ času, ko je bilo izobraževanje že $v$ teku, anketiranci pa so se $v$ času anketiranja že kar nekaj časa izobraževali in imeli glede na močno prilagojenost izobraževalnih vsebin, metod, ocenjevanja, kriterijev itd. že zelo dober vpogled v zahtevnost izobraževanja, kar je njihova pričakovanja o uspešnosti pri učenju še povečalo. Pričakovati je, da bi bili rezultati zelo drugačni, če bi anketiranje potekalo pred začetkom izobraževanja. Še dodaten razlog za manjšo pomembnost samoučinkovitosti pri odločitvah za nadaljevanje izobraževanja pa je specifičnost populacije $-v$ vzorec so vključeni le brezposelni, ki so bili za izobraževanje že motivirani, niso pa bili zajeti tisti, ki se niso želeli izobraževati.

Raziskava je potrdila tudi predpostavko glede vpliva samoučinkovitosti na vrsto učne motivacije (notranja in zunanja motivacija). Rezultati analize varianc in korelacijskih 
Ob ustrezni motivaciji brezposelnega za izobraževanje je potrebno vzpostaviti tudi ustrezne materialne pogoje tega izobraževanja, ki so za ciljno skupino brezposelnih še posebej pomemben dejavnik. Državni interes vključevanja v izobraževanje te ciljne populacije bi se moral izražati predvsem v finančnem omogočanju izobraževanja (možnosti povračila cene izobraževalnega programa, stroškov prevoza, učnih gradiv, varstva otrok ipd.) in na ta način stimulirati manj izobražene brezposelne (in zaposlene) za izobraževanje.

analiz so pokazali, da je samoučinkovitost pozitivno povezana $\mathrm{z}$ notranjo motivacijo, negativno pa je $\mathrm{z}$ njo povezana zunanja motivacija. Vrsta motivacije je povezana tudi s stališči do izobraževanja. Pri brezposelnih, ki so bolj notranje motivirani, so stališča močneje izražena kot pri tistih, ki so bolj zunanje motivirani za učenje. V skladu s temi rezultati so tudi rezultati varianc, s katerimi smo primerjali vrsto učne motivacije in samoučinkovitosti glede na različne sociodemografske značilnosti brezposelnih: notranja motivacija in večja samoučinkovitost sta bolj izraženi pri ženskah in starejših brezposelnih, vključenih $v$ daljše oblike izobraževanja, in tistih, ki imajo višje aspiracije.

Poudariti moramo tudi izstopajoč pomen samoučinkovitosti, ki vpliva tako na izobraževalne aspiracije brezposelnih kot tudi na njihov odnos do učenja. Ta dejavnik je pomemben pri brezposelnih, ki so bili pripravljeni za vključitev $\mathrm{v}$ izobraževanje. Predvidevamo lahko, da je pri izobraževalno neaktivnih problem še bolj pereč. To bi bilo potrebno upoštevati tako pri načrtovanju izobraževanja in njegovi izvedbi kot tudi pri motiviranju brezposelne osebe za vključitev vanj.

\section{LITERATURA}

Bandura, A. (1986). Social foundation of thought and action: a social cognitive theory. Englewood Cliffs, New York: Prentice-Hall.
Becker, E. A. \& Gibson, C. C. (1999). Fishbein and Ajzen's theory of reasoned action: accurate prediction fo behravioral intentions for enrolling in distance education courses. Adult Education Quarterly, let. 49, št. 1, str. 43-55.

Bezinović, P. (1988). Samopercepcija osobne kompetentnosti kao dimenzija vrednovanja vlastitog ja. (disertacija). Zagreb: Sveučilište u Zagrebu, odsjek za psihologiju.

Courtney, S. (1992). Why adults learn: towards a theory of participation in adult education. London: Routledge.

Drofenik, O. idr. (2001). Evalvacija srednješolskega formalnega izobraževanja brezposelnih - Program 5000: fazno poročilo. Ljubljana: Andragoški center Slovenije.

Furnham, A. (1994). The psychosocial consequences of youth unemployement. V A. C. Petersen in J. T. Mortimer (ur.), Youth unemployement and socicty. Cambridge University Press.

Howard, K. W. (1989). A comprehensive expectancy motivation model: implications for adult education and training. Adult Education Quarterly, let. 39, št. 4, str. 199-210.

Musek, J. (2000). Nova psihološka teorija vrednot. Ljubljana: Inštitut za psihologijo osebnosti, Educy.

Pogačnik, V. (1987). LV, lestvica individualnih vrednot: priročnik. Ljubljana: Zavod SR Slovenije za produktivnost dela, Center za psihodiagnostična sredstva.

Pryor, B. W. (1990). Predicting and explaining intentions to participate in continuing education: an application of the theory of reasoned action. Adult Education Quarterly, let. 40, št. 3, str. 146-157.

Radovan, M. (2003). Vrednotni, kognitivni in socialnokulturni vidiki motivacije odraslih za izobraževanje: analiza motivacije brezposelnih v Programu 5000 [magistrsko delo]. Ljubljana: Filozofska fakulteta, Oddelek za psihologijo.

Rubenson, K. (1987). Participation in recurrent education: A research review. V H. G. Schütze \& D. Istance (ur.), Recurrent education revisited: Modes of participation and financing, (str. 39-67). Stockholm: Almqvist \& Wiksell International.

Ule, M. \& Miheljak, V. (1995). Pri(e)hodnost mladine. Ljubljana: DZS, Ministrstvo za šolstvo in šport, Urad Republike Slovenije za mladino.

'Podrobnejši opis instrumentarija, metodologije in statističnih analiz, na katere se sklicujem $v$ tem prispevku, je na voljo v publikaciji; Radovan, $M$. (2003). Vrednotni, kognitivni in socialno-kulturni vidiki motivacije odraslih za izobraževanje: analiza motivacije brezposelnih v Programu 5000 [magistrsko delo]. Ljubljana: Filozofska fakulteta, Oddelek za 